\title{
THE INLAND WATERWAYS OF THE SOUTH
}

\author{
By J. F. Ellison,
}

Secretary, National Rivers and Harbors Congress, Cincinnati, $O$.

The New South, not the old, self-satisfied South of pleasant memories and tender recollections, that lay ever half asleep basking in her own sunshine, content to raise the cotton supply of the world and to allow her wonderful natural resources of mine and forest to remain undisturbed, but the New South, awakening as a young giant, strong and vibrant, throwing off the fetters of commercial indifference, is at last aroused, or should I say being aroused, to the fact that the beneficent hand of the Creator has given to her more natural advantages than He has vouchsafed to any other part of this great Union.

South of that invisible, but once sharply defined boundary, Mason and Dixon Line, now, thanks be, nearly forgotten, lies a mighty empire, greater in natural resources than the combined empires of Great Britain, France and Germany. Great in the fertility of its soil, great in the undeveloped and hardly touched wealth of its mines of coal, iron and stone, and greater still in the wealth of its forests, where stands to-day the timber reserve of this country, it is greatest of all in the extent of its navigable streams that cross and intersect its states, all winding their way either to ocean or gulf. No similar section of North America, or for that matter of the globe, is so blessed with natural highways and gateways, rivers and harbors, as is the southern group of these United States.

Recognizing that the foregoing is a strong statement, as proof of its correctness, let me present the figures on this subject given in the report of the National Conservation Commission, as follows: In the United States there is a total of 26,4 IO miles of navigable streams; of this total there lie within the states of the South I 8,215 miles of inland rivers, navigable now in part and susceptible of being made so in whole. 


\section{Southern Navigable Rivers}

Tributary to the Atlantic Ocean ........... 4,567 miles Tributary to the Gulf of Mexico ............ 5,212 miles Tributary to the Mississippi River and thence to the Gulf ....................... 7,073 miles The Mississippi River in southern territory ........ I, 363 miles

I8,2 15 miles

This estimate does not include the Mississippi River above St. Louis, or the Missouri or Ohio River, the waters of which mark the northern boundary of southern states for nearly I,000 miles, all joining to make the mighty Mississippi, the "Father of Waters," that flows in a never-ending volume through the very heart of the Southland. Contemplate, if you can, picture in your mind's eye, if it be within your power, what 18,215 miles of navigable waters mean as a commercial asset to the states of the South, for has it not been proven beyond the question of a doubt that water-borne commerce is the cheapest form of carriage known to man? Has it not been proven that transportation charges, which fix the price to the consumer and define the profit to the producer, add nothing to the value of a commodity, but are a tax alike upon both?

Has the South availed itself of this wonderful asset of 18,215 miles of inland rivers that the Conservation Commission has said are navigable waters? No, and again most emphatically no, but it is not the fault of the states of the South, for the federal government has assumed, and rightly so, jurisdiction and ownership over all the navigable waters of the United States. To quote the exact words of Secretary of State Knox on this subject: "The duty of the government to raise its waterways and harbors to their utmost efficiency was determined long ago by the action of the government itself. It invited cities to improve their docks to accommodate large ocean vessels. It held out inducements to railways to bring their tracks to the water's edge and construct terminals for the transfer of freight from cars to vessels. So when the government assumed charge and control of the navigable streams of the interior it entered into a practical contract with the states and communities bordering these streams that their waterways would be 
improved to their highest capacity. The states were thereby prevented from improving the streams themselves. Corporate enterprise was forbidden to undertake the canalization of important stretches and fix the cost of their works and franchises on the traffic. The federal government has made its formal and deliberate declaration that it will do this work. That necessarily involves that it will make the improvements adequate to modern needs and possibilities. To do any less would be a mockery and breach of good faith."

"To do any less would be a mockery and breach of good faith." Strong words these from a strong man. Has the federal government kept this faith with the states of the Union? The answer to this question can well be made by using the language of one of the really great men that this nation has produced, Theodore Roosevelt, who said, "The rivers of no other civilized country are so poorly developed, so little used or play so small a part in the industrial life of the nation, as those of the United States." Again strong words that naturally beget the question, "Why have these God-given channels of transportation been so neglected by this government, which is a government of the people and by the people?" The writer, realizing that where there are many men there are many minds, gives it as his opinion that the fault is not with the national government nor with those who represent the people as national legislators, but with the people themselves, for is it not a conceded fact that what the people of this country unite in demanding they receive from the national government? They have demanded a navy, army and pensions to such an extent that this nation, which delights to call itself and be so called by other nations of the earth, a peaceful, mercantile nation, is to-day paying a greater percentage of its total revenues for war and its rewards than is any other. They demanded an Isthmian Canal, not for the reason that there was foreign commerce enough to justify the expenditure of so vast a sum as it will cost, not that there was a merchant marine of our own to use it, but because, with characteristic American optimism, they believed the time would come, as come it will, when our own merchant ships, carrying our own products of field, forest and factory to the markets of the South Americas and the Orient, returning laden with the products of those countries which we use but do not produce, will keep the placid waters of the Panama Canal, our own canal, in 
constant motion as they pass to and fro from ocean to ocean. I said this time would come, but it will not be until the inland rivers of the South and all other parts of the country that are blessed with inland rivers have been improved so that they will have become dependable routes to tide water, whether it be on the Atlantic, the Gulf or the Pacific, so that the merchant and manufacturer located in the interior can put his goods on shipboard at rates that will allow him to compete in the open markets of the world with the output of Europe.

Will these inland rivers ever be improved, so that their navigation will be at all times dependable? Aye, surely. When? When the people of this country awaken to the fact, as have already the master minds and builders of railroads, that high noon in railway development has been reached. Mr. James J. Hill, who has recently succeeded to the title of "Colossus of Roads," has said that it would require five billion dollars and a larger industrial army than any of the standing armies of the Old World to put rail lines in condition to carry the constantly expanding commerce of the country. Mr. Hill truthfully adds that neither the money nor the men are available.

Compare these stupendous figures with the half billion dollars named by waterway experts as the sum necessary to improve the rivers and harbors of the nation that have been surveyed and favorably reported upon to Congress by the United States Army Engineer Corps as being worthy of improvement, and the improvement of which would add to the transportation facilities of the sections in which they are located. Has it not been truthfully said that the chief element in the prosperity of every state and nation is the economy of transportation of persons and property, which economy it is conceded by all authorities and proven by all experience is furnished by water? The author has stated elsewhere that

When the people who compose this great republic, from whom all legislative power emanates, realize that with our waterways improved the congestion of the American railway system will be eliminated; that for practical purposes every question of transportation will be solved; that the era of moderate freight rates will be permanently installed and that the many problems that now confront both shipper and receiver, vex the Interstate Commerce Commission and clog our courts will no longer exist, for improved waterways would be rate regulators, the decisions of which would be just and from which no appeal would be possible, they will rise in their might and 
demand of their representatives in the National Congress that laws be enacted that will provide and put into effect a national waterway policy, a policy that will require, first, careful examination and close study of all river and harbor improvement projects before the same are undertaken, but, when once undertaken, will provide that the work be carried on steadily and systematically to rapid completion. A policy that will provide the funds necessary; a policy that, if the current revenues of the country will not furnish these funds, will provide for the sale of bonds, the proceeds of such bonds to be used exclusively in the payment of such waterway improvement work as has been authorized by Congress. Such a policy is not a new idea or proposition, except as it applies to our rivers and harbors, for it is exactly in line with the one adopted and put into effect by the government in the building of the Panama Canal. After it was once determined that the canal should be built provision was made to carry on the work to completion as rapidly as money and men could do it, and the money has been furnished by the sale of United States bonds.

The demand of the people for this kind of policy must be a universal demand. After-dinner speakers delight in telling us that there is now no north, south, east or west, but a united people, going forward under the old flag. If this be true, then should the people of all states and sections of states of this Union unite and with one voice make their demands known, never fearing but that they will be granted by the national lawmakers, for be it known to all men that under the great dome of the Capitol of Washington there never was framed and put upon the statute books a law that was not first demanded by the people. Congress never initiates legislation; it only acts when dictated to by the people or those whom the people have put into high places. These national lawmakers, these congressmen, are not a people apart, but of us and with us, willing, as I truly believe, at all times to give to the people that which in their wisdom the people ask; but they are wise men who do not enact legislation that their constituents do not both endorse and demand.

Therefore, I say again that when the people of this country want their waterways improved and say so, and say it at the polls, then will the work commence and not end until every mile of the many miles of inland rivers is put into a condition to bear its full share of transportation burdens.

Then the South, with its vast store of undeveloped resources of mine and forest, the products of which not only require, but 
must have cheap transportation from the point where produced to the manufacturer's door to make them valuable, and which her I8,2 I 5 miles of improved waterways will furnish, will come unto her own. The population of every state will increase, cities will take the place of hamlets and where now is heard only the whir of the cotton gin great manufacturing plants will spring up to convert the raw materials of the land into finished products that will enrich not only the South, but the nation, for that which is to the betterment of one section of our common country is to the advantage of all. Then truly will there arise a new South, equipped to go into the markets of the world and to battle with all the nations thereof to maintain the commercial supremacy of the Union of which it is so important a part. 